\title{
METODE PEMBELAJARAN SIMULASI DAN DEMONTRASI DI LABORATORIUM DENGAN HASIL BELAJAR MATA KULIAH KEPERAWATAN KEGAWATDARURATAN DI AKADEMI KEPERAWATAN KESDAM I/BB MEDAN MEDAN
}

\section{Method of Simulation and Demonstration Learning in Laboratory With Emergency Learning Outcomes in Nursing Academy of Kesdam I/BB Medan}

\author{
Resmi Pangaribuan', Muchti Yuda Pratama \\ ${ }^{1,2}$ Dosen Tetap Yayasan Wahana Bhakti Karya Husada, \\ Akademi Keperawatan Kesdam I/BB Medan \\ Email: resmi.pangaribuan@yahoo.co.id,yudamuchti@yahoo.co.id
}

\begin{abstract}
Abstrak
Asuhan keperawatan kegawatdaruratan merupakan proses keperawatan dalam mengelola pasien atau penderita untuk mendapatkan asuhan mandiri maupun multidisiplin (kolaboratif) sehingga dapat tercapai kriteria hasil yang diharapkan. Proses pembelajaran melibatkan aktivitas yang kompleks, bukan sekedar transfer of knowledge dari pendidik kepada peserta didik secara tekstual. Dalam setiap pembelajaran, harus diupayakan untuk dapat mengantarkan peserta didik pada pengusaan kompetensi yang dicanangkan, termasuk nilai-nilai dan sikap yang melandasinya. Desain penelitian ini bersifat studi korelasi dengan menggunakan rumus Slovin yaitu jumlah sampel yang diambil dari populasi terjangkau pada penelitian ini. Hasil penelitian yang dilakukan secara statistik menunjukkan Mahasiswa Akademi Keperawatan Kesdam I/BB Medan mengetahui tentang metode pembelajaran simulasi kategori cukup sebanyak 30 mahasiswi (46,9\%). Mahasisiwi Akademi Keperawatan Kesdam I/BB MedanMedan mengetahui tentang metode pembelajaran demonstrasi kategori cukup sebanyak 34 mahasisiw (53,1\%). Mahasisiwi Akademi Keperawatan Kesdam I/BB MedanMedan tentang hasil belajar asuhan keperawatan kegawatdarurtan kategori nilai $\mathrm{C}$ sebanyak 35 mahasiswi (54,7\%). Diharapkan Bagi Akademi Keperawatan Kesdam I/BB Medan Medan untuk Mempertahankan dan semakin meningkatkan sarana dan prasarana laboratorium untuk mendukung tercapainya mahasiswi pada asuhan kebidanan ibu bersalin di Akademi Keperawatan Kesdam I/BB Medan.
\end{abstract}

Kata Kunci : pembelajaran simulasi, demonstrasi, hasil pembelajaran mata kuliah keperawatan kegawatdaruratan

\begin{abstract}
Emergency nursing care is a nursing process in managing patients or patients to get independent and multidisciplinary care (collaborative) so that the expected outcome criteria can be achieved. The learning process involves complex activities, not just the transfer of knowledge from educators to students textually. In each learning process, efforts must be made to be able to deliver students to the proposed competency, including the underlying values and attitudes. The design of this study is a correlation, The sampling technique is to use the Slovin formula, namely the number of samples taken from affordable populations in this study. The results of the research conducted statistically showed that the Students of Nursing Academy of Kesdam I/BB Medan knew that there were 30 female students (46.9\%) in the simulation category. Student of Nursing Academy in Medan I/BB Medan know about the adequate method of demonstration learning method as many as 34 students (53.1\%). Students of Nursing Academy of Kesdam I/BB Medan about the learning outcomes of emergency nursing care from the category C value of 35 female students (54.7\%). It is expected that the Medan I/BB Middle School Nursing Academy will maintain and further improve laboratory facilities and infrastructure to support the achievement of female students in midwifery care at the Nursing Academy of Kesdam I/BB.
\end{abstract}

Keywords: simulation learning, demonstration, learning outcomes for emergency nursing courses 


\section{PENDAHULUAN}

Asuhan keperawatan kegawatdaruratan merupakan proses keperawatan dalam mengelola pasien atau penderita untuk mendapatkan asuhan mandiri maupun multidisiplin (kolaboratif) sehingga dapat tercapai kriteria hasil yang diharapkan. Pertolongan pertama dalam kegawatdaruratan selalu bertujuan untuk menyelamatkan pasien atau penderita tanpa membahayakan penolong. (Selvia, 2016).

Proses pembelajaran melibatkan aktivitas yang kompleks, bukan sekedar transfer of knowledge dari pendidik kepada peserta didik secara tekstual. Dalam setiap pembelajaran, harus diupayakan untuk dapat mengantarkan peserta didik pada pengusaan kompetensi yang dicanangkan, termasuk nilai-nilai dan sikap yang melandasinya. Oleh karena itu pembelajaran tidak harus selalu dilaksanankan di kelas. Adakalanya pembelajaran harus dilaksanakan di laboratorium atau di lapangan. Dalam hal ini tentu diperlukan strategi dan ketrampilan yang berbeda.

Metode demonstrasi merupakan metode mengajar dengan menggunakan peragaan untuk menjelaskan suatu pengertian atau untuk memperlihatkan bagaimana berjalnnya suatu proses pembentukan tertentu pada mahasiswa. Untuk memperjelas pengertian tersebut dalam prakteknya dapat dilakukan. Metode demonstrasi cukup baik apabila digunakan dalam penyampaian bahan pembelajaran Kegawatdaruratan.

Namun UGD dan klinik kedaruratan sering di gunakan untuk masalah yang tidak urgen. Yang kemudian filosopi tentang keperawatan gawat darurat menjadi luas, kedaruratan yaitu apapun yang dialami pasien atau keluarga harus dipertimbangkan sebagai gedaruratan. Pelayanan gawat darurat tidak hanya memberikan pelayanan untuk mengatasi kondisi kedaruratan yang dialami pasien tetapi juga memberikan asukan keperawatan untuk mengatasi kecemasan pasien dan keluarga.

Berdasarkan survei awal yang dilakukan penulis di Akademi Keperawatan Kesdam I/BB Medan tahun 2016 pada awal bulan Februari tahun 2016 pada semester IV tentang keterampilan penanganan asuhan keperawatan kegawatdaruratan yaitu dari 70 mahasiswi terdapat 25 mahasiswi diantaranya mengaku merasa lebih mengerti pembelajaran metode simulasi dan demonstrasi dengan belajar di laboratorium dibanding dengan pembelajaran teori di dalam kelas, selain itu mereka juga mengatakan bahwa pembelajaran asuhan keperawatan kegawatdaruratan dengan teori cukup membosankan. Nilai hasil belajar asuhan keperawatan kegawatdaruratan kategori mayoritas nilai $\mathrm{C}$ sebanyak 35 mahasiswi $(54,7 \%)$. Sarana yang digunakan dalam penanganan asuhan keperawatan kegawatdaruratan sudah lengkap dan mengatakan merasa lebih mengerti pembelajaran metode simulasi dan demonstrasi dengan belajar di laboratorium karena sarana prasarana yang lengkap serta tidak membingungkan karena langsung menggunakan alat yang dibutuhkan pada penanganan asuhan persalinan normal dibandingkan dengan pembelajaran teori di dalam kelas yang kurang dimengerti karena tidak langsung menunjukkan alat dan fungsinya pada penanganan asuhan persalinan normal.

\section{METODE}

Desain penelitian ini bersifat studi korelasi yaitu penelitian atau penelaahan hubungan antara dua variabel pada suatu situasi atau sekelompok subjek. Hal ini dilakukaan untuk melihat hubungan antara satu dengan variabel yang lain (Notoadmodjo, 2010).

\section{HASIL DAN PEMBAHASAN}

Penelitian ini dilakukan di Akademi Keperawatan Kesdam I/BB Medan.

Jalan Putri Hijau No. 17 Medan (komplek

Rumah Sakit TK II Putri Hijau Medan)

Tabel 1. Distribusi Frekuensi

\begin{tabular}{clcl}
\hline No & $\begin{array}{c}\text { Metode } \\
\text { Pembelajaran } \\
\text { Simulasi }\end{array}$ & Frekuensi & $\begin{array}{c}\text { Persentase } \\
(\boldsymbol{\%})\end{array}$ \\
\hline 1. & Baik & 6 & 9,4 \\
2. & Cukup & 30 & 46,9 \\
3. & Kurang & 28 & 43,8 \\
\hline & Jumlah & 64 & 100 \\
\hline
\end{tabular}


Dari tabel 1 dapat dilihat bahwa mahasiswi Akademi Keperawatan Kesdam I/BB MedanMedan mengetahui tentang metode pembelajaran simulasi kategori cukup sebanyak 30 mahasiswi (46,9\%).

Tabel 2. Distribusi Frekuensi

\begin{tabular}{llll}
\hline No & $\begin{array}{c}\text { Metode } \\
\text { Pembelajaran } \\
\text { Demonstrasi }\end{array}$ & $\begin{array}{c}\text { Freku- } \\
\text { ensi }\end{array}$ & $\begin{array}{c}\text { Persen- } \\
\text { tase (\%) }\end{array}$ \\
\hline 1 & Baik & 7 & 10,9 \\
2 & Cukup & 34 & 53,1 \\
3 & Kurang & 23 & 35,9 \\
\hline & Jumlah & 64 & 100 \\
\hline
\end{tabular}

Dari tabel 2 dapat dilihat bahwa mahasiswi Akademi Keperawatan Kesdam I/BB Medan mengetahui tentang metode pembelajaran demonstrasi kategori cukup sebanyak 34 mahasiswi $(53,1 \%)$.

Tabel 3. Distribusi Frekuensi

\begin{tabular}{cclc}
\hline No & $\begin{array}{c}\text { Nilai Kep. } \\
\text { Gadar }\end{array}$ & Frekuensi & $\begin{array}{c}\text { Persentase } \\
(\mathbf{\%})\end{array}$ \\
\hline & Nilai A & 8 & 12,5 \\
Nilai B & 14 & 21,9 \\
Nilai C & 35 & 54,7 \\
Nilai D & 7 & 10,9 \\
\hline Jumlah & 64 & 100 \\
\hline
\end{tabular}

Dari tabel 3 dapat dilihat bahwa mahasiswi Akademi Keperawatan Kesdam I/BB Medan tentang hasil belajar Asuhan Keperawatan Kegawatdaruratan kategori nilai C sebanyak 35 mahasiswi $(54,7 \%)$.

Berdasarkan hasil uji chi square Hubungan Metode Pembelajaran Simulasi dilaboratorium Dengan Hasil Belajar Mata Kuliah Asuhan keperawatan kegawatdarurtan di Akademi Keperawatan Kesdam I/BB MedanMedan Tahun 2017, dengan derajat kemaknaan $(\alpha)=0,1 \quad$ dan $\quad \mathrm{df}=6$ diperoleh hasil perhitungan yaitu $X^{2}{ }_{\text {hitung }} 44,895$. $X_{\text {tabel }}^{2}$ 12,592. Maka Ho ditolak dan $\mathrm{Ha}$ diterima. Kesimpulannya terdapat ada Hubungan Metode Pembelajaran Simulasi dilaboratorium dengan Hasil Belajar Mata Kuliah keperawatan kegawatdaruratan di Akademi Keperawatan Kesdam I/BB Medan.

Dari tabel di atas dapat dilihat bahwa mahasiswi Tingkat III Akademi Keperawatan Kesdam I/BB Medan yang mengetahui metode pembelajaran simulasi dilaboratorium kategori cukup dengan hasil belajar mata kuliah asuhan keperawatan kegawatdarurtan kategori nilai $\mathrm{C}$ sebanyak 25 mahasiswi $(39,1 \%)$ dan berdasarkan hasil uji chi square Hubungan Metode Pembelajaran Simulasi di laboratorium.

Dengan Hasil Belajar Mata Kuliah keperawatan kegawatdaruratan di Akademi Keperawatan Kesdam I/BB Medan Tahun 2016, dengan derajat kemaknaan $(\alpha)=0,1$ dan $\mathrm{df}=6$ diperoleh hasil perhitungan yaitu $X^{2}$ hitung $44,895^{a}>X^{2}$ tabel 12,592. Maka Ho ditolak dan Ha diterima. Kesimpulannya terdapat ada Hubungan Metode Pembelajaran Simulasi dilaboratorium dengan Hasil Belajar Mata Kuliah keperawatan kegawatdaruratan di Akademi Keperawatan Kesdam I/BB Medan Tahun 2016.

Penelitian Netty Herawaty Purba tentang Hubungan Motivasi Ekstrinsik Dalam Pembelajaran Laboratorium dengan Kemampuan dalam Asuhan Persalinan Normal Mahasiswa Semester V Akademi Kebidanan Imelda Medan periode 2008/2009. Dengan sampel 50 orang. Instrument dalam penelitian ini adalah angket dengan 20 pertanyaan tentang motivasi ekstrinsik yang terdiri atas kualitas dosen, bobot materi kuliah, kondisi dan suasana pembelajaran serta fasilitas laboratorium. Hasil analisa data diperoleh dari tabel diatas menunjukkan bahwa Motivasi ekstrinsik dalam pembelajaran laboratotium paling banyak dalam Motivasi Sedang yaitu 33 orang $(64,0 \%)$, dan paling sedikit dalam Motivasi Rendah yaitu 17 orang $(34,0 \%)$.

Asumsi peneliti adalah metode pembelajaran simulasi dilaboratorium dapat meningkatkan hasil belajar pada mata kuliah asuhan keperawatan kegawatdarurtan karena dilaboratorium dilatih dan diajarkan kompetensi-kompetensi asuhan keperawatan kegawatdarurtan.

Hubungan Metode Pembelajaran Demonstrasi dilaboratorium Dengan Hasil Belajar Mata Kuliah Asuhan keperawatan kegawatdarurtan di Akademi Keperawatan Kesdam I/BB MedanMedan Tahun 2017. 
Metode demonstrasi ialah metode mengajar dengan menggunakan peragaan untuk memperjelas suatu pengertian atau untuk memperlihatkan bagaimana berjalannya suatu proses pembentukan tertentu pada mahasiswi. Untuk memperjelas pengertian tersebut dalam prakteknya dapat dilakukan. Metode demonstrasi cukup baik apabila digunakan dalam penyampaian bahan pelajaran kebidanan (Maryana, 2011).

Demonstrasi adalah metode yang digunakan untuk membelajarkan peserta dengna cara menceritakan dan memperagakan suatu langkah-langkah pengerjaan sesuatu. Metode demonstrasi dapat dibagi menjadi dua tujuan yaitu demonstrasi proses untuk memahami langkah demi langkah dan demonstrasi hasil untuk memperlihatkan atau memperagakan hasil dari sebuah proses. Biasanyaa, setelah demonstrasi dilanjutkan dengan praktek oleh peserta ssendiri. Sebagai hasil, peserta akan memperoleh pengalaman belajar langsung setelah melihat, melakukan dan merasakan sendiri (Prana, 2011).

Metode pembelajaran dengan menggunakan metode demonstrasi dilaboratorium pada mata kuliah asuhan keperawatan kegawatdarurtan mempermudah mahasiswi dalam menguasai teori yang dipelajari dikelas.

Asumsi peneliti metode demonstrasi sangat perlu dilakukan pada mata kuliah asuhan keperawatan kegawatdarurtan karena mempermudah mahasiswi dalam menguasai teori yang dipelajari dikelas. Dalam laboratorium ini akan dilatih dan diajarkan kompetensi-kompetensi Asuhan Keperawatan Kegawatdaruratan. Laboratorium dibentuk dan dikondisikan mirip dengan kenyataan yang ada dilapangan sehingga mahasiswi dapat melatih dan mengaplikasikan keterampilan seusai dengan kompetensi yang diharapkan .

\section{KESIMPULAN DAN SARAN Kesimpulan}

Dari hasil penelitian di Akademi Keperawatan Kesdam I/BB MedanMedan dengan judul Hubungan Metode Pembelajaran Simulasi dan Demonstrasi di laboratorium Dengan Hasil Belajar mata Kuliah Asuhan keperawatan kegawatda- ruratan di Akademi Keperawatan Kesdam I/BB Medan, dapat disimpulkan bahwa :

1. Mahasiswa Akademi Keperawatan Kesdam I/BB Medan mengetahui tentang metode pembelajaran simulasi kategori cukup sebanyak 30 mahasiswi $(46,9 \%)$.

2. Mahasisiwi Akademi Keperawatan Kesdam I/BB Medan mengetahui tentang metode pembelajaran demonstrasi kategori cukup sebanyak 34 mahasisiw $(53,1 \%)$.

3. Mahasisiwi Akademi Keperawatan Kesdam I/BB Medan tentang hasil belajar asuhan keperawatan kegawatdaruratan kategori nilai $\mathrm{C}$ sebanyak 35 mahasiswi $(54,7 \%)$.

\section{Saran}

Bagi Akademi Keperawatan Kesdam I/BB Medan Medan untuk mempertahankan dan semakin meningkatkan sarana dan prasarana laboratorium untuk mendukung tercapainya mahasiswi pada asuhan kebidanan ibu bersalin di Akademi Keperawatan Kesdam I/BB Medan. Memberikan bimbingan secara lebih intensif di laboratorium kepada mahasiswa dengan memperhatikan metode pembelajaran yang digunakan dalam pencapaian kompetensi dalam mata kuliah asuhan keperawatan kegawatdarurtan. Mempersiapkan mahasiswa sebelum mengikuti praktek klinik kebidanan baik dari segi teori maupun praktek laboratorium sehingga mahasiswa siap melakukan asuhan kebidanan pada ibu bersalin.

\section{DAFTAR PUSTAKA}

Arikunto, S. 2010. Prosedur Penelitian. Jakarta : Rineka Cipta.

Daryanto dan Tasrial, 2012. Konsep Pembelajaran Kreatif. Penerbit Gava Media. Cetakan ke-1. Yogyakarta.

Dewi, 2011. Hubungan Pembelajaran Laboratorium dengan Pencapaian Kompetensi Mahasiswa dalam melakukan Insersi IUD. http://www.reposiyi.usu.ac.id/bitstre 
am/.../chapter\%2011. Diakses tanggal 2 Juli 2012.

Depkes RI, 2007. Asuhan Persalinan Normal. Jakarta : Departemen Kesehatan Republik Indonesia.

Dwi, N, 2012. Evaluasi hubungan skill laboratorium asuhan kebidanan II metode osca dengan prestasi belajar asuhan kebidanan II di STIKES 'Aisyiyah Surakarta Tahun 2010. http://www.id.shvoong.com >... Radiologi. Diakses tanggal 7 september 20112.

Hidayat, A, Alimul, A. 2011. Metode Penelitian Kebidanan dan teknik Analisa Data. Jakarta : Salemba Medika.

Isriani, H, Puspitasari, D. 2012. Strategi Pembelajaran Terpadu (Teori, Konsep dan Implementasi). Group Relasi Inti Media. Yogyakarta.

Musfah, J, 2010. Peningkatan Kompetensi Guru Melalui Pelatiahan dan
Sumber Belajar Teori dan Praktek, cetakan ke-1. Jakarta : Kencana.

Notoadmodjo, S. 2010. Metodologi Peneitian Kesehatan. Jakarta : PT Rineka Cipta.

N.K., Roestiyah, 2007. Strategi Belajar Mengajar. Jakarta : Rineka Cipta.

Mine, 2010. Metode Demonstrasi. http://32mine.blogspot.com/2010/04 Imetode-demonstrasi.html. Diakses pada tanggal 30 Mei 2012.

Prana, 2011. Metode Demontrasi yang dilakukan di laboratorium. http://file.upi.edu/Direktori/KDSUMEDANG/19721226200501100 2. diakses pada tanggal 1 juni 2012.

Yulianty, 2011. http://www Model Pembelajaran role Playing,com. Diakses pada tanggal 28 April 2012.

Zaini, H. 2008. Strategi Pembelajaran Aktif. Yogyakarta : Pustaka Insan madani. 